\title{
Dividend Policy: A Comparative Study of UK and Bangladesh Based Companies
}

\author{
MD. ZAHANGIR ALAM ${ }^{1}$, Mohammad Emdad Hossain \\ ${ }^{I}$ Assistant Professor of Finance, Department of Business Administration, International Islamic University \\ Chittagong, Bangladesh, \\ ${ }^{2}$ Assistant Professor of Statistics, Department of Business Administration, International Islamic University \\ Chittagong, Bangladesh,
}

\begin{abstract}
The paper is about Dividend Policy: A Case of UK based Companies. The objective of the study is to critically examine the dividend policy of UK based companies listed in London Stock Exchange i.e., the theories of organizational dividend policy, arguments for and against of dividend, and determinants of dividend policy. The study also examines the influence of liquidity, leverage, profitability, growth, and ownership structure, and market capitalization on the dividend rate. The study reveals that as per dividend irrelevance theory dividend policy has no influence on value of the firm for the reason of home made dividend ; according to dividend relevance theory, value of the firm is influenced by dividend policy because of certainty, information content and clientele effect; liquidity, availability of worthwhile projects, availability of alternative funds, profitability, growth, leverage, reaction of market to dividend reduction, ownership structure nature of the industry, tax clientele effect are the main determinants of dividend payout ratio. In case of the UK based companies, leverage; profitability; market capitalization influence the dividend rate positively, whereas liquidity and growth have negative impact on dividend payout ratio. Liquidity; leverage; profitability; and market capitalization influence the dividend rate negatively, while growth affect positively in case of a Bangladeshi company.
\end{abstract}

\section{Key Words: Dividend, Dividend Policy, Dividend Policy Theories, Home Made Dividend.}

\section{Introduction}

In the field of corporate finance, the finance manager has to take three important decisions, namely investment decision which is related to where the given company should make investment; financing decision which is concerned with the determination of how the required fund would collected; and dividend decision which may arise when the firm makes profits. Should the firm distribute its all earnings to the shareholders or should it be reinvested into the business? Financial managers must give concentrations on how much the company's earnings are required for investment in projects with positive NPV and the possible effects of their decision on shares prices (Bishop, et al. 2000).

Dividend policy is formulated by the board of directors of a company in order to make decision how much earnings would distributed among the shareholders as their reward for making investment in the given company in the form of dividend and how much would be retained within the company as a retained earnings. Dividend policy is an important area of research in corporate finance. Even though a number of researches have been conducted on dividend policy, a limited number of studies have revealed the applicability of the dividend theory on some listed companies in an organized stock exchange.

\section{Literature Review}

Gupta and Banga (2010) found in their study that there are some determinants, namely leverage, liquidity, profitability, growth and ownership structure of the firm influence the dividend policy of a firm. The findings of Baker and Powell's (2000) research regarding the determinants of dividend policy are rate of present and prospective earnings, pattern of the dividend payment, and nature of the industry. Alli, Khan and Ramirez (1993) in their study found strong support in favour of the residual theory of dividends, pecking order argument, and the role of dividends in mitigating the agency problems, and tax clientele argument. Akhigbe and Madura (1996) argued that dividend initiations have favourable impact on the performance of share price in the long run and the opposite in case of the dividend omissions; the immediate share price response and the one-year cumulative abnormal returns for firms initiating dividends are positively correlated; in case of omitting dividends, between the immediate share price response and long-term valuation effects have no significant relation; the post effect of dividend initiations' firms are significantly higher growth, higher capital investment, a higher degree of financial leverage, and a higher dollar amount of earnings and vice versa; and the long-term 
valuation effects of dividend omissions are more unfavourable for larger firms and for relatively large dividend omissions.

Yilmaz and Gulay (2006) found in their study that "prices start to rise a few sessions before cash dividend payments; and on the ex-dividend day; they fall less than do dividend payments; finally decreasing in the sessions following the payment; trading volume shows a considerable upward shift before the payment date; is stable after, therefore, cash dividends influence prices and trading volumes in different ways before, at, and after payment, providing some profitable active trading strategy opportunities around the ex-dividend day". Gillet, Lapointe and Raimbourg (2008) claimed that the signalling equilibrium becomes unbalanced, originating any dividend signalling policy to become difficult to implement. Dhanani (2005) argued that the research results sustain dividend proposition related to signalling and ownership structure, in liking to those about capital structure and investment decisions and agency issues. Moreover, he revealed significant differentiations between managers' responses, based on company size, industry sector, growth opportunities, ownership structure, and information asymmetry.

Howatta etl (2009) found in their study that change in dividends and future changes in mean real EPS are correlated in the same direction. Moreover, a significant variation of EPS due to change in dividend is experienced for all changes associated dividend except for the omissions of dividend. Hardin and Hill (2008) revealed that excess dividend payment is associated with reduced agency costs, strong operating performance, the execution of a stock repurchase plan and the capability to access short-term bank debt. In addition, REIT management flexibility in formulating dividend policy is influenced by the acquisitions and use of short-term bank debt. The outcomes of Kim and Wonsiksu (2010) are foreign institutional investors can put forth an important impact on dividend if they hold more than 5\% of a company shares and the more shares that foreign institutional investors have over the previous year, the stronger the impact of foreign institutional investors have on the corporate dividend policy. Papadopoulos and Charalambidis (2007) found in their study that dividend payout policy is focused to small changes through years; the difference between the retail firms and industrial firms in terms of dividend policy are not remarkable; and cash flow of the firm is the main determinant of dividend policy.

According to Baker, Farrelly and Edelman (1985), stakeholders are highly concerned with the continuity of dividend, share value is affected by dividend policy, the concerned persons are generally aware of signalling and clientele effects and regulated firms should be segregated from non-regulated firms in order to examine the dividend policy. As per the outcomes of Naceu, Goaied and Belanes's (2006) study, Tunisian firms consider both the present earnings and past dividends in order to determine the level of dividend payment; profitable firms with more stable earnings and faster growth pay higher dividend due to the capability to afford larger free cash flows. Moreover Brennan and Thakor (1990) found in their research that majority shareholders of a firm are in favour of dividend payment for small distributions regardless of the preferential tax treatment of capital gains for individual investors; majority shareholders may prefer an open market stock repurchase for larger distributions; and tender offer repurchases for the largest distributions. Banerjee, Gatchev and Spindr (2007) argued that more (less) liquid common stock holders are less (more) likely to receive cash dividend; and historic liquidity is a significant determinant of dividend initiations and omissions.

\section{Objectives of the Study}

i. To present the theories of organizational dividend policy

ii. To produce arguments for and against that a high cash dividend payout ratio as possible would reflect positively on the market value of shares

iii. To place arguments for and against that whether a cash dividend is paid or not is irrelevant in the context of shareholders wealth maximization

iv. To put arguments for and against that dividend payment should be avoided as they would lead to decrease in shareholders wealth

v. To indentify the determinants of dividend policy

vi. To examine the influence of liquidity, leverage, profitability, growth, and ownership structure, and market capitalization on the dividend rate.

\section{Research Methodology}

Data and Sample

The necessary data have been collected from the annual report of the sample enterprises, namely TESCO plc, BP plc and BT plc, listed in London Stock Exchange. The period of the study is ten years, ranging from 2001 to 2010. Only final cash dividends paid by the companies have been considered and we have ignored stock dividend and stock repurchases by the companies. Specification of the Variables:

\section{Dependent Variable:}

Dividend Rate (DR): The percentage of cash dividend paid to the common shareholders. 


\section{Independent Variables:}

Liquidity: Liquidity has been measured by cash flows from operation (CFO) which is net profit before tax and extraordinary income adjusted to non-cash charges and receipts.

Leverage: Leverage has been expressed in terms of debt-equity ratio (DER) which is the proportional relationship between total debt and equity

Profitability: Profitability has been characterised as return on investment (ROI) which is the proportional relationship between the net profit after tax and total assets

Growth: Growth has been measured in terms of percentage change in EPS (G)

Market Capitalization: It corresponds to the size of the firm (S) which is log of the total assets

\section{Specification of the Econometrics Model}

The following econometrics model has been used to examine the influence of liquidity, leverage, profitability, growth, and size of the firm (market capitalization) on dividend rate of the sample enterprises: $D R=\alpha_{1}+\beta_{1} C F O+\beta_{2} D E R+\beta_{3} R O I+\beta_{4} G+\beta_{5} S+u_{i}$

\section{Theories of Dividend Policy}

\section{Findings and Analysis}

Dividend Irrelevance Theory: Modigliani and Miller (1961) argued that share valuation is a function of the level of corporate earnings, which reflects a company's investment policy, rather than a function of the proportion of a company's earnings that are paid out as dividends, i.e. the wealth of a company's shareholders is determined by the earning power and risk of its assets not by the dividend payout decision. M \& M established that dividend policy is irrelevant under certain assumptions about perfect capital markets, such as there is no difference between dividend and capital gain from the view point of taxes; securities trading is free from transaction cost and floatation cost; symmetrical and cost less information are available for all investors; there is no conflict between managers and shareholders in respect of interest; and all investors are treated as price takers in the market ( Al-Malkawi, Rafferty and Pillai, 2010).

Dividend Relevance Theory: Linter (1956) and Gordon (1959) argued that shareholders prefer dividends to capital gain which is called the 'Bird-in-the-Hand argument which represents that shareholders have a preference to receive an assured dividend payment at the present more willingly than leaving the same amount in an investment whose future value is uncertain. Since, current dividends are more reliable return than capital gains and shareholders prefer dividends to capital gains, therefore dividend policy plays a crucial role in the determination of the market value of a company.

\section{Arguments for and against that a High Cash Dividend Payout Ratio as Possible would reflect positively on the Market Value of Shares}

One group agrees with the statement that a high cash dividend payout ratio as possible would reflect positively on the market value of shares, on the contrary another group disagrees with such statement. Therefore, it is a debatable issue

\section{Arguments in Favour of the Debate}

As per the opinions of a certain group of people, a high cash dividend payout ratio is positively reflected in the market value of shares due to the following grounds:

Dividend Reduces Uncertainty: Dividend reduces uncertainty about the future cash flows which leads to decrease the cost of capital as a result shareholders wealth increases through increasing the market value of the shares.

Higher Future Dividend: Gordon (1961) argued that a certain amount of dividend is more worthy than the same amount of retained earnings, since investors may earn higher future dividend from a new project in exchange of higher degree of risk. If the firm announces lower dividend in order to make greater investments, therefore the dividend pattern would be shifted into the future and company value would be fallen, since the investors assess the expected dividend by using the higher discount rate.

Information Content: If any company's board of directors recommends for a higher cash dividend for a certain period compare to the previous period, it's regarded as a good signal to the shareholders which indicates that the cash position of the given company has increased which lead to increase the share price of that company and shareholders wealth as well. 
Clientele Effect: There are some investors, especially aged group, prefer dividend as a source of their continuous income.

Certainty about the Company's Future: If any company pays higher cash dividend to the shareholders, it gives more certainty about its future to the investors and the increase in certainty may be correlated to directly increase in the company's share price in the market.

\section{Arguments Against of the Debate}

On the other hand, another group of people disagrees with the statement that a high cash dividend payout ratio is positively reflected in the market value of shares due to the following grounds:

Tax Liability: Cash dividend payment causes the tax liability to the shareholders, since they have to pay tax on their income received in the form of cash dividend.

Scarcity of Cash: High cash dividend payout ratio causes decreased in retained earnings which lead to shortage of cash for making investment in order to create growth of the company.

Bird -in-Hand- Fallacy: M \& M (1961) argued that the risk of a firm is determined by the riskiness of its operating cash flows, not by the way it distributes its earnings which are called the bird-in-hand fallacy.

Reinvestment is Inefficient: The shareholders, especially wealthy middle-aged, who receive large amount of dividends in cash, they would probably reinvest in the stock market. This is regarded as the cycle of receiving dividends followed by reinvestment which is very inefficient ( Arnoland, 2008 ).

\section{Arguments for and against that whether a Cash Dividend is Paid or not is Irrelevant in the context of Shareholders Wealth Maximization}

A certain group of people agrees with the statement that whether a cash dividend is paid or not is irrelevant in the context of shareholders wealth maximization, on the contrary another group disagrees with such statement. Therefore, it is a matter of debate.

\section{Arguments in Favour of the Debate}

A certain group of people agrees with the statement that whether a cash dividend is paid or not is irrelevant in the context of shareholders wealth maximization for the following logics:

Earning Power of the Firm: According to dividend discount model (DDM), value of a stock is a function of future dividends and its required rate of return which can be expressed in the following way:

$\mathrm{P} 0=\sum \frac{\infty t}{(1+r t)^{t}} \quad \ldots \ldots \ldots \ldots . . . .$.

Where,

$\mathrm{P} 0=$ the current share price;

$\mathrm{t}=$ time of the dividend;

$\mathrm{Dt}=$ dividend paid at period $\mathrm{t}$;

$\mathrm{rt}=$ required rate of return for period $\mathrm{t}$

Equation (1) represents that the fundamental determinants of today's share price the future discounted dividends, not any future share price.

In case of the perfect capital market, the required rate of return on equity is the sum of dividends and capital gains which can be expressed by the following equation:

$\mathrm{r}=\frac{D 1+(P 1-P 0)}{P 1}$

Where,

$\mathrm{D} 1=$ the expected dividend at the end of the period 1

$\mathrm{P} 1=$ the ex-dividend price of the share

$\mathrm{P} 0=$ the current market price of the share.

We can determine the current market price of share by rearranging the equation 2 :

$\mathrm{P} 0=\frac{D_{1}+P_{1}}{(1+r)}$

The current value of the firm is:

$\mathrm{np}_{0}=\mathrm{V}_{0}=\frac{n D_{1+n P_{1}}}{(1+r)}$

Where, 
$\mathrm{N}=$ number of shares outstanding at time zero.

We can consider the following sources and uses of funds equation to illustrate the M \& M (1961) statement regarding the dividend policy and value of the firm:

$\mathrm{CF}_{1}+\mathrm{mP}_{1}=\mathrm{nD}_{1}+\mathrm{I}_{1}$

By rearranging equation (5), we get

$\mathrm{nD}_{1}=\mathrm{CF}_{1}+\mathrm{mP}_{1}-\mathrm{I}_{1}$

Substituting equation (6) into equation (4), for $\mathrm{D}_{1}$ we have

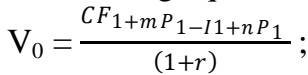

$\mathrm{V}_{0}=\frac{C F_{1-L_{1+(n+m) P}}}{(1+r)}$

Since $(\mathrm{n}+1) \mathrm{p}_{1}=\mathrm{V}_{1}$, therefore

$\mathrm{V}_{0}=\frac{C F_{1}-I_{1}+V_{1}}{(1+r)}$

Therefore, we can say firm's future cash flows, i.e. earnings generated from investment activities is the key determinant of the value of the firm not the dividend policy, since dividends do not appear in equation (9) and operating cash flows $\left(\mathrm{CF}_{1}\right)$, investments $\left(\mathrm{I}_{1}\right)$ and the required rate of return $(\mathrm{r})$ are not the functions of dividend policy ( Al-Malkawi, Rafferty and Pillai, 2010).

Home Made Dividends: There are some group of shareholders who may prefer current income, however such group of shareholders, in case of the efficient capital market, would not be worse off if the company does not announce dividend, since they can realize income by selling a part of their shareholdings in the form of homemade dividend (Pike and Neal, 2006).

Cash Flows: Firm's investment with positive NPV projects increase the cash flows from operation, which is the solely way to increase the shareholders wealth not the payment of cash dividend.

\section{Arguments Against of the Debate}

On the other hand, another group of people disagrees with the statement that whether a cash dividend is paid or not is irrelevant in the context of shareholders wealth maximization by reason of the following arguments:

Transaction Cost and Floatation Cost: Pike and Neal (2006) argued that even though in the presence of efficient capital market, shareholders are capable to earn return by selling a part of their shareholdings, but such benefit may be offset for some reasons, namely brokerage and other transaction costs are involved with selling of share; shareholders may not be able to sell the precise number of required shares; selling of share may generate tax liability on capital gain; and in case of a relatively small company, its shares may have lack of marketability which may require a noteworthy dealing spread and consequently a outflow of shareholder capital.

Dividends as Conveyers of Directors View: Dividend policy is a matter, since an unexpected change in dividend is regarded as a sign of how the directors view the future prospects of the firm. A declining dividend often signals that the directors view of the future with some pessimism, whereas increase in dividend indicates an optimistic view about future probability (Arnoland, 2008).

\section{Arguments for and against that Dividend Payment should be Avoided as they would Lead to Decrease in Shareholders Wealth}

A certain group of people agrees with the statement that dividend payment should be avoided as they would lead to decrease in shareholders wealth; on the contrary another group disagrees with such statement. Therefore, it is a matter of debate.

\section{Arguments in Favour of the Debate}

A certain group of people disagrees with the statement that dividend payment should be avoided as they would lead to decrease in shareholders wealth for the following judgments:

Tax Consequence: Dividend payment causes more tax burden for the shareholders, since tax on dividends is higher than capital gains. Therefore, company's board of directors should retain total cash flows rather than paying dividends which will increase the shareholders wealth (Watson and Head, 2007).

Cost of Policy Formulation: Some administrative costs are involved with the formulation of dividend policy which decreases the earnings of the given company. There is an adverse impact of reduction of earnings on the market share price of share, as a result the shareholders wealth decreases. 
Transaction Costs: Both the firm and shareholders incur costs for dividend payment, since company has to bear cost in distributing dividends and investors has to incur costs in collecting and reinvesting these payments as well (Bhattacharya, 1979).

Cost of Capital: Avoidance of dividend payment reduce the need for external financing which plays an important role in reducing the cost of capital of the firm, since cost of external financing is higher than internal financing. Due to reduction of cost of capital, value of the firm increased, because there is an inverse relationship between cost of capital and value of the firm.

Default Risk: Dividend payment causes the requirement of external financing and if such external financing is made in the form of issuance of new shares, it is a threat for the existing shareholders in the context of dilution their controlling power. In order to maintain the controlling power, if debt is issued to meet up the required fund, it increases the financial risk of the company which is reflected in their share price unfavourably.

Tax Free: Due to avoidance of dividend payment, market price of share could grow tax free.

\section{Arguments Against of the Debate}

Bad Signal: Avoidance of dividend payment is treated as negative signal about the future prospect of the company which has unfavourable impact on the market price of share as well as the shareholders wealth.

Withdrawal of Investment: If any company avoid the dividend payment, it leads to withdraw investment from the given company by the existing shareholders which play a negative role in shareholders wealth maximization.

\section{Determinants of Dividend Policy}

Liquidity: It is the ability of a company to convert its current assets into cash without significant concession of price and time which can be measured by current ratio (i.e. the proportional relationship between current assets and current liabilities) and cash generated from operations. There is a positive relationship between liquidity and level of dividend payment of a firm (Benito and Young, 2001).

Availability of Worthwhile Projects: The board of directors of a company should consider this factor to determine the level of dividend payment. They should pay lower dividend if worthwhile projects are available.

Availability of Alternative Funds: If the required fund is collected at cheaper rate than the cost of retained earnings the level of dividend should be higher, otherwise not.

Profitability: It measures the earnings power of a company. Return on Investments (ROA) and Return on Equity (ROE) are the main indicators of the profitability which positively influence the level of dividend of a firm (Gupta and Banga, 2010).

Growth: Growth is one of the factors which should be considered in determining the level of dividend of a company. Growth can be measured in terms of sales, EPS, and market share on annual basis. Growth and level of dividend payment are positively correlated ( Kania and Bacon, 2005).

Leverage: It is the level of debt used by the firm which may be measured by the Debt- Equity Ratio. Leverage affects the level of dividend payment inversely (Gupta and Banga, 2010)

Reaction of Market to Dividend Reduction: The board of directors should consider the effects of reduction in dividend payout on the stakeholders expectation, homemade dividends, information content and information to shareholders.

Ownership Structure: Ownership structure of a company may be represented by the proportion of shareholdings by the directors, institutions and foreign investors. Directors prefer to lower level of dividend payment, whereas institutional investors are in favour of higher level of dividend (Han, Lee and Suk, 1999)

Nature of the Industry: It is one of the factors which play an important role in determining the level of dividend payment. High dividend payout should be for utilities industry, whereas the more moderate payout for the wholesale/retail trade groups (Baker and Powell, 2000). 
Tax Clientele Effect: Tax effect also plays a crucial role in formulating the dividend policy. Higher tax bracket shareholders are against of cash dividend in order to avoid heavy tax and on the other hand, lower tax payers prefer more cash dividend (Gupta and Banga, 2010).

\section{Figure 1: The Forces Pulling Management in the Dividend Decisions}

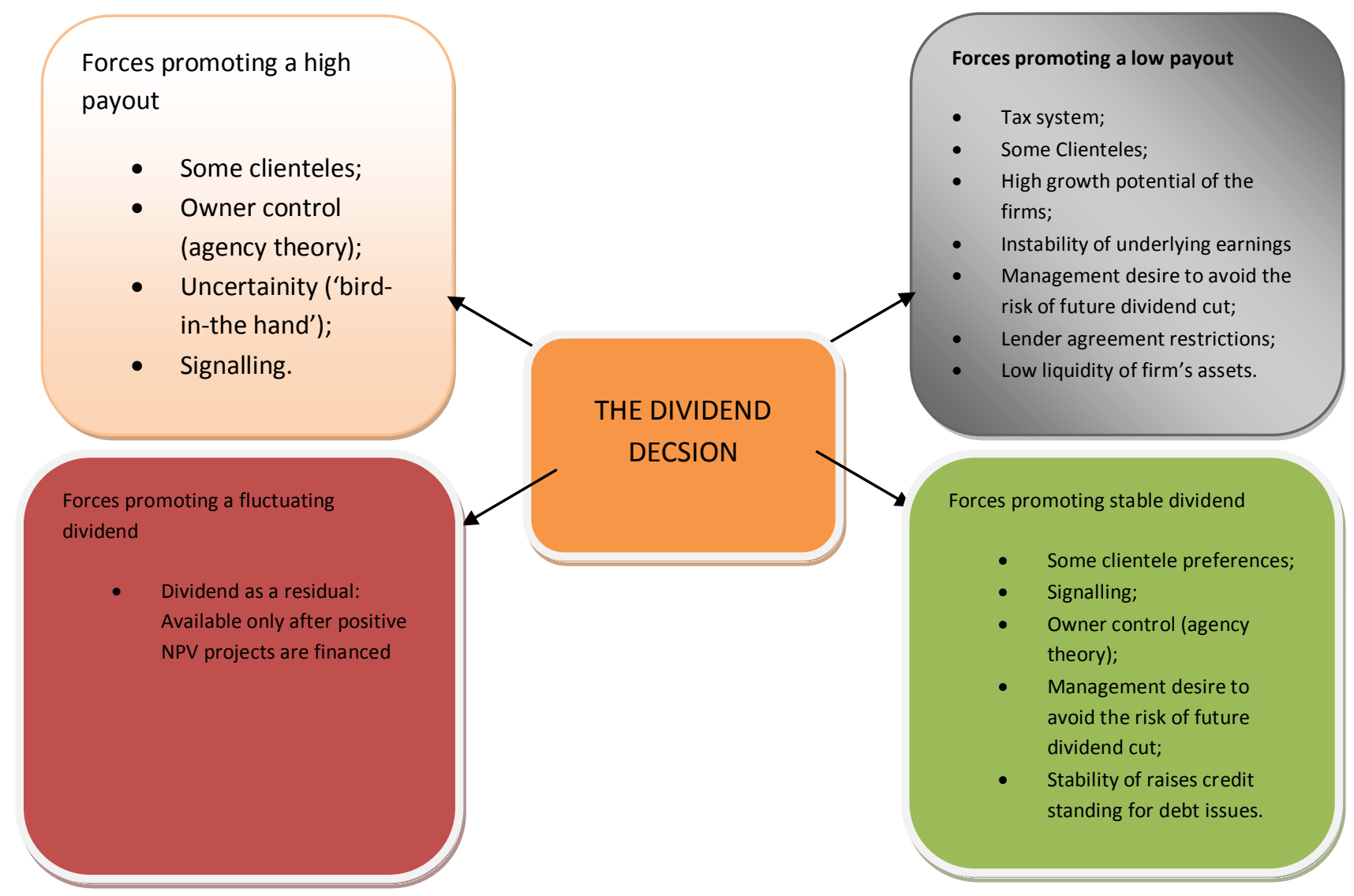

VII. Influence of Liquidity, Leverage, Profitability, Growth, and Ownership Structure, and Market Capitalization on the Dividend Rate

III.2 UK Based Companies

Using the SPSS17 statistical package, we obtained the following results:

DR = -3.618-0.494CFO +0.108DER +0.650ROI - 0.038 G + $\mathbf{0 . 6 8 8 S}$ (Appendix 3 by using statistical package SPSS17 ) and $\mathbf{R}$-squared $\mathbf{= 0 . 2 8 4}$

-0.494 is the partial regression coefficient of cash flows and indicates that with the influence of others ( leverage, profitability, growth and market capitalization) held constant, as cash flows changes, say by one percent, on average, dividend rate changes by 0.494 percent in the opposite direction. 0.108 is the partial regression coefficient of leverage and indicates that with the influence of others held constant, as leverage changes, say by one percent, on average, dividend rate changes by 0.108 percent in the same direction. 0.650 is the partial regression coefficient of profitability and indicates that with the influence of others held constant, as growth changes, say by one percent, on average, dividend rate changes by 0.650 percent in the same direction. 0.038 is the partial regression coefficient of growth and indicates that with the influence of others held constant, as growth, say by one percent, on average, dividend rate changes by 0.038 percent in the opposite direction.

$0.688 \mathrm{~S}$ is the partial regression coefficient of market capitalization and indicates that with the influence of others held constant, as market capitalization changes; say by one percent, on average, dividend rate changes by 0.688 percent in the same direction. The intercept value of -3.618 , mechanically interpreted, means that if the values of cash flows, leverage, profitability, growth and market capitalization were fixed at zero, the dividend rate would be -3.618 . The $\mathrm{R}$-squared value of 0.284 means that 28.40 percent of the variation in dividend rate is explained by cash flows, leverage, profitability, growth and market capitalization. 


\section{Bangladesh Based Company}

Using the SPSS17 statistical package, we obtained the following results:

DR $=70.808-0.097$ CFO $-0.601 D E R ~-0.044$ ROI +0.233G -0.654S (Appendix 4 by using statistical package SPSS17) and R-squared $\mathbf{= 0 . 4 9 1}$

-0.097 is the partial regression coefficient of cash flows and indicates that with the influence of others ( leverage, profitability, growth and market capitalization) held constant, as cash flows changes, say by one percent, on average, dividend rate changes by 0.097 percent in the opposite direction. -0.601 is the partial regression coefficient of leverage and indicates that with the influence of others held constant, as leverage changes, say by one percent, on average, dividend rate changes by 0.601 percent in the opposite direction.

-0.044 is the partial regression coefficient of profitability and indicates that with the influence of others held constant, as growth changes, say by one percent, on average, dividend rate changes by 0.044 percent in the opposite direction.

0.233 is the partial regression coefficient of growth and indicates that with the influence of others held constant, as growth, say by one percent, on average, dividend rate changes by 00.233 percent in the same direction. 0.654 is the partial regression coefficient of market capitalization and indicates that with the influence of others held constant, as market capitalization changes; say by one percent, on average, dividend rate changes by 0.654 percent in the opposite direction. The intercept value of 70.808 , mechanically interpreted, means that if the values of cash flows, leverage, profitability, growth and market capitalization were fixed at zero, the dividend rate would be 70.808 . The $\mathrm{R}$-squared value of 0.491 means that 49.10 percent of the variation in dividend rate is explained by cash flows, leverage, profitability, growth and market capitalization.

\section{Conclusion}

Dividend policy is concerned with the determination of level of dividends for the shareholders of a company. As per dividend irrelevance theory ( $\mathrm{M} \& \mathrm{M}, 1961$ ), the value of the firm is unaffected by dividend policy in a perfect world, since the firm's value is determined exclusive by the earning power and the risk of its investment. On the contrary, according to dividend relevance theory (Gordon, 1956) \& (Linter, 1959), value of the firm is influenced by the dividend policy, because of the current dividend decreases the shareholders uncertainty, causing the shareholders to discount the company's earnings at a lower rate which increases the company's stock value and value of the firm as well (Gitman, 2009). A high cash dividend payout ratio as possible would reflect positively on the market value of shares for the reasons of certainty, higher future dividend, information content, clientele effect, certainty about the company's future earnings. On the contrary, a high cash dividend payout ratio as possible would reflect positively on the market value of shares due to tax liability, scarcity of cash, bird -in-hand- fallacy, and inefficient fund for reinvestment.

A cash dividend is paid or not is irrelevant in the context of shareholders wealth maximization, because of homemade dividends, cash flows, and replacement by having a new issue of shares. On the other hand, a cash dividend is paid relevant in the context of shareholders wealth maximization due to transaction cost and floatation cost, dividends as conveyers of directors' view about the future prospect of the company's performance. Dividend payment should be avoided as they would lead to decrease in shareholders wealth for the reason of tax consequences, cost of policy formulation, transaction cost, and cost of capital, default risk, and tax free. On the contrary, avoidance of dividend payment would lead to decrease in shareholders wealth for the reason of bad signal and withdrawal of investment.

The board of directors should consider some crucial factors to determine the level of dividend payment, namely liquidity, availability of worthwhile projects, availability of alternative funds, profitability, growth, leverage, reaction of market to dividend reduction, ownership structure nature of the industry, tax clientele effect and so on.

In case of UK based companies, while other things remain constant, the influence of liquidity, leverage, profitability, growth and market capitalization on dividend is $0.494,0.108,0.650,0.038$, and 0.688 in the opposite, same, same, opposite and same direction . Mechanically, the dividend is -3.618 in absences of liquidity, leverage, profitability, growth and market capitalization. 28.40 percent of the variation in dividend rate is explained by cash flows, leverage, profitability, growth and market capitalization. In case of Bangladesh based company, while other things remain constant, the influence of liquidity, leverage, profitability, growth and market capitalization on dividend is $0.097,0.601,0.044,0.233$, and 0.654 in the opposite, opposite, opposite, same and opposite direction respectively. Mechanically, the dividend is 70.808 in absences of liquidity, leverage, profitability, growth and market capitalization. 49.10 percent of the variation in dividend rate is explained by cash flows, leverage, profitability, growth and market capitalization. In conclusion, it can be mentioned that the degree of influence of liquidity, leverage, profitability, growth and market capitalization on dividend rate is higher in case of Bangladeshi Company compared to the UK based company. 


\section{References}

1. Akhigbe, A. and Madura, J. (1996) 'Dividend policy and corporate performance', Journal of Business Finance \& Accounting, 23(9) \& (10), pp. $1267-1287$.

2. Alli, K., L., Khan, A., Q., and Ramirez, G., G. (1993) 'Determinants of corporate policy: a factorial analysis', The Financial Review, 28 (4), pp. $523-547$.

3. Al-Malkawi, H.-A., N., Rafferty , M., and Pillai, R. (2010) 'Dividend policy: a review of theories and empirical evidence', International Bulletin of Business Administration, 9, pp. 7-18

4. Arnold, G. (2008) Corporate financial management. $4^{\text {th }}$ edn. Harlow: Pearson Financial Times.

5. Baker, H., K., Farrelly, G., E. and Edelman, R., B. (1985) 'A survey of management views on dividend policy', Financial Management, 14(4), pp. 78-84.

6. Baker, H. K. and Powell, G., E. (2000) 'Determinants of corporate dividend policy: a survey of NYSE firms', Financial Practice \& Education, 10 ( 1), pp. 29-40.

7. Banerjee, S., Gatchev, V., A., and Spindr, P., A. (2007) 'Stock market liquidity and firm dividend policy', Journal of Financial and Quantitative Analysis, 42 (2), pp. 367-398.

8. Benito, A. and Young, G. (2001) 'Hard times and great expectations? Dividend omissions and dividend cuts by UK firms', Working Paper, Bank of England, ISSN 1368 - 5562.

9. Bhattacharya, S., ( 1979) 'Imperfect information, dividend policy, and " the bird in the hand" fallacy', Bell Journal of Economics, 10, pp. 259-270.

10. Bishop, S., R., Harvey, R., C., Robert, W., F., and Garry, J., T. (2000) Corporate finance. Sydney: Prentice Hall Inc.

11. Brennan, M., J. and Thakor, A., V. ( 1990) 'Shareholder preferences and dividend policy', The Journal of Finance, 14 (4), pp.993 -1018 .

12. Dhanani, A. (2005) 'Dividend policy: the views of british financial managers', Journal of Business Finance \& Accounting, 32(7) \& (8), pp. $1625-1672$.

13. Gillet, R., Lapointe, M- A., and Raimbourg, P. (2008) 'Dividend policy and reputation, Journal of Business Finance \& Accounting, 35(3) \& (4), pp. 516-540.

14. Gitman, L., J. (2009) Principles of managerial finance. $12^{\text {th }}$ edn. Boston; London : Pearson Prentice Hall.

15. Gordon, M. (1959) 'Dividends, earnings and stock prices', Review of Economics and Statistics, 41, pp. 99-105.

16. Gupta, A., and Banga, C. (2010)' The determinants of dividend policy', Indian Institute of Management Calcutta, 37 (2), pp. 6377.

17. Han K. C., Lee, S. H. and Suk, D, Y. (1999) 'institutional shareholders and dividends', Journal of Financial and Strategic Decisions, $12(1)$, pp. $53-62$.

18. Hardin, W. and Hill, M., D. (2008) 'REIT Dividend Determinants: Excess Dividends and Capital Markets', Real Estate Economics, 36 (2), pp. 349-369.

19. Howatta, B., Zuberb, R., A., Gandarc, J., M. and Lambd, R., P. (2009) 'Dividends, earnings volatility and information', Applied Financial Economics, 19, 551-562.

20. Kania, S .L and Bacon, F. W. (2005) 'What factors motivate the corporate dividend decision'?, ASBBS E-Journal, 1(1), pp. 97 107.

21. Kim, S. and Wonsiksul (2010) 'Impact of foreign institutional investors on dividend policy in Korea: a stock market perspective', Journal of Financial Management and Analysis, 23(1), pp. 10-26.

22. Linter, J.(1959) 'Distribution of incomes of corporations among dividends, retained earnings and taxes', American Economic Review, 46, pp. 97-113.

23. Miller, M., H., and Kevin, R. (1985) 'Dividend policy under asymmetric information', Journal of Finance, 40, pp. $1031-1051$.

24. Miller, M. H. and Modigliani, F. (1961) 'Dividend policy, growth and the valuation of shares', The Journal of Business, 34( 4), pp. 411-433.

25. Naceur, S., B., Goaied, M. and Belanes, A. (2006) 'Determinants and dynamics of dividend policy', International Review of Finance, 6 (1) \& (2), pp. 1-23.

26. Papadopoulo, D., L. and Charalambidis, D., P. (2007) 'Focus on present status and determinants of dividend payout policy: Athens stock exchange in perspective', Journal of Financial Management and Analysis, 20(2), pp. 24-37.

27. Pike, R., and Neal, B. (2006) Corporate finance and investment: decisions \& strategies. $5^{\text {th }}$ edn. Harlow : Financial Times Prentice Hall.

28. Watson, D., and Head, A. (2007) Corporate finance: principles \& practice. $4^{\text {th }}$ edn. Harlow : Prentice Hall.

29. Yilmaz, M., K. and Gulay, G. (2006) 'Dividend policies and price-volume reactions to cash dividends on the stock market: evidence from the Istanbul stock exchange, Emerging Markets Finance and Trade, 42 (4), pp. 19-49.

\section{Appendices}

Appendix 1: Dividend Rate, Cash Flows from Operation, ROI, Growth and Size of TESCO, BP and BT from 2001 to 2009

\begin{tabular}{|l|l|l|l|l|l|l|}
\hline DIV & CFO & DER & ROI & Growth & Size & CFO \% \\
\hline 0.534884 & 4825 & 0.018282 & 0.099324 & -0.024820 & 4.015360 & 0.231315 \\
\hline-2.600000 & 4706 & 0.006269 & -0.018310 & 0.033134 & 4.018409 & 0.220009 \\
\hline 0.748815 & 5486 & 0.016712 & 0.155262 & 0.023785 & 4.048985 & 0.264973 \\
\hline 0.449405 & 5210 & 0.003930 & 0.279115 & 0.036333 & 4.009366 & 0.257627 \\
\hline 0.657459 & 5387 & 0.005734 & 0.154846 & 0.058875 & 3.999870 & 0.276058 \\
\hline 0.488263 & 5574 & 0.002777 & 0.180874 & -0.025640 & 4.004837 & 0.302458 \\
\hline 0.521472 & 5389 & 7.603103 & 0.053235 & -0.062830 & 4.425175 & 0.284921 \\
\hline 0.209677 & 6023 & 9.680167 & 0.095191 & -0.074860 & 4.450511 & 0.298434 \\
\hline
\end{tabular}


Dividend Policy: A Comparative Study of UK and Bangladesh Based Companies

\begin{tabular}{|l|l|l|l|l|l|l|}
\hline-0.057470 & 5257 & 1.546478 & 0.021555 & 0.035457 & 4.664266 & 0.240981 \\
\hline 0.382353 & 5887 & 3.546126 & -0.034120 & -0.038120 & 4.738773 & 0.279429 \\
\hline-0.729550 & 13616 & 1.839286 & -0.012210 & 0.241712 & 5.434987 & 0.045829 \\
\hline 0.639708 & 21716 & 1.310852 & 0.071022 & -0.337460 & 5.372853 & 0.090759 \\
\hline 0.493456 & 38095 & 1.477977 & 0.094925 & 0.269998 & 5.358399 & 0.105485 \\
\hline 0.392248 & 24709 & 1.494147 & 0.089670 & 0.069419 & 5.373052 & 0.086892 \\
\hline 0.352294 & 28172 & 1.546083 & 0.102417 & 0.108903 & 5.337661 & 0.105947 \\
\hline 0.333429 & 26721 & 1.561927 & 0.109379 & 0.248761 & 5.315790 & 0.111434 \\
\hline 0.360349 & 23378 & 1.493060 & 0.090326 & 0.166234 & 5.281279 & 0.121745 \\
\hline 0.458551 & 21698 & 1.417480 & 0.073936 & -0.078710 & 5.232137 & 0.131780 \\
\hline 0.789214 & 19342 & 1.292570 & 0.043016 & 0.025847 & 5.201738 & 0.108225 \\
\hline 0.757576 & 22409 & 1.178757 & 0.046179 & 0.076576 & 5.152197 & 0.128626 \\
\hline 0.447071 & 4745 & 2.134868 & 0.050562 & 0.052351 & 4.662975 & 0.075875 \\
\hline 0.440678 & 3960 & 2.530451 & 0.046813 & 0.147818 & 4.658622 & 0.066637 \\
\hline 0.404453 & 3343 & 1.540554 & 0.070415 & 0.110746 & 4.479489 & 0.064570 \\
\hline 0.408302 & 2611 & 1.346703 & 0.076269 & 0.080534 & 4.394574 & 0.056017 \\
\hline 0.433233 & 2619 & 1.389136 & 0.069849 & 0.167221 & 4.353397 & 0.060714 \\
\hline 0.436994 & 2176 & 1.328981 & 0.066782 & 0.101320 & 4.304383 & 0.058879 \\
\hline 0.458138 & 2942 & 1.336312 & 0.059261 & 0.186598 & 4.268625 & 0.087672 \\
\hline 0.461997 & 2375 & 1.532382 & 0.057330 & 0.102362 & 4.217510 & 0.083982 \\
\hline 0.461285 & 2038 & 1.451356 & 0.061228 & 0.126510 & 4.132132 & 0.079442 \\
\hline 0.467167 & 4825 & 1.356770 & 0.061456 & 0.118627 & 4.069372 & 0.080666 \\
\hline$S 0 u r C: A n$ & $R e p r$ & $B P$ & $0.6 B T(2001-2010)$ & & & \\
\hline
\end{tabular}

Source: Annual Report of TESCO, BP and BT ( 2001-2010)

Appendix 2: Dividend Rate, Cash Flows from Operation, ROI, Growth and Size of Islami Bank Bangladesh Ltd. (IBBL), United Leasing and Beximco Pharma Ltd. from 2001 to 2009

\begin{tabular}{|l|l|l|l|l|l|l|}
\hline Year & DER & Liquidity & ROA $(\%)$ & Dividend & MKT CAP & Growth \\
\hline 2001 & 144.5691164 & 3418.64 & 0.8 & 25 & 4.77 & 0 \\
\hline 2002 & 293.9402985 & 3940.02 & 0.92 & 25 & 4.89 & 1.033216401 \\
\hline 2003 & 407.7840317 & 1335.33 & 0.53 & 20 & 4.99 & 0.38730223 \\
\hline 2004 & 812.6689093 & 2949.976653 & 1.1 & 0 & 5.1 & 0.992890467 \\
\hline 2005 & 385.6695525 & 1896.458077 & 1 & 0 & 5.18 & -0.525428439 \\
\hline 2006 & 17.02567948 & 5076.35 & 1.03 & 0.15 & 5.27 & -0.95585423 \\
\hline 2007 & 15.71460996 & 11496.68 & 0.84 & 0 & 5.4 & -0.077005415 \\
\hline 2008 & 14.50807395 & 16495.08 & 1.27 & 0 & 5.46 & -0.07677798 \\
\hline 2009 & 13.42172863 & 11534 & 1.34 & 0.1 & 5.53 & -0.074878673 \\
\hline 2010 & 14.62268737 & 3329.73 & 1.47 & 0 & 5.65 & 0.089478694 \\
\hline
\end{tabular}

Source: Annual Report of IBBL (2001-2010)

Appendix 3: Regression Result for UK Based Companies Model Summary

\begin{tabular}{|l|l|l|l|l|}
\hline Model & $\mathrm{R}$ & R Square & Adjusted R Square & Std. Error of the Estimate \\
\hline 1 & $.533^{\mathrm{a}}$ & .284 & .135 & .57132 \\
\hline \multicolumn{2}{|l|}{ a. Predictors: (Constant), Size, Growth, DER, ROI, CFO } \\
\hline
\end{tabular}


Dividend Policy: A Comparative Study of UK and Bangladesh Based Companies

\begin{tabular}{|c|c|c|c|c|c|c|}
\hline \multicolumn{7}{|c|}{$\mathrm{ANOVA}^{\mathrm{b}}$} \\
\hline \multicolumn{2}{|c|}{ Model } & Sum of Squares & df & Mean Square & $\mathrm{F}$ & Sig. \\
\hline \multirow[t]{3}{*}{1} & Regression & 3.107 & 5 & .621 & 1.904 & $.131^{\mathrm{a}}$ \\
\hline & Residual & 7.834 & 24 & .326 & & \\
\hline & Total & 10.940 & 29 & & & \\
\hline
\end{tabular}

a. Predictors: (Constant), Size, Growth, DER, ROI, CFO

b. Dependent Variable: DIV

Coefficients

\begin{tabular}{|c|c|c|c|c|c|c|}
\hline \multicolumn{2}{|r|}{ Model } & \multicolumn{2}{|c|}{ Unstandardized Coefficients } & \multirow{2}{*}{$\begin{array}{c}\begin{array}{c}\text { Standardized } \\
\text { Coefficients }\end{array} \\
\text { Beta }\end{array}$} & \multirow[t]{2}{*}{$\mathrm{t}$} & \multirow[t]{2}{*}{ Sig. } \\
\hline & & B & Std. Error & & & \\
\hline \multirow[t]{6}{*}{1} & (Constant) & -3.618 & 2.220 & & -1.630 & .116 \\
\hline & $\mathrm{CFO}$ & $-2.967 \mathrm{E}-5$ & .000 & -.494 & -1.164 & .256 \\
\hline & DER & .033 & .056 & .108 & .579 & .568 \\
\hline & ROI & 6.632 & 2.267 & .650 & 2.925 & .007 \\
\hline & Growth & -.194 & .920 & -.038 & -.210 & .835 \\
\hline & Size & .799 & .511 & .688 & 1.562 & .131 \\
\hline
\end{tabular}

a. Dependent Variable: DIV

Appendix 4: Regression Result of Bangladeshi Company

Model Summary

\begin{tabular}{|l|l|l|l|l|}
\hline Model & R & R Square & Adjusted R Square & Std. Error of the Estimate \\
\hline 1 & $.977^{\mathrm{a}}$ & .954 & .896 & 3.66161 \\
\hline
\end{tabular}

a. Predictors: (Constant), Liquidity, Growth, ROI, DER, MKT

ANOVA $^{b}$

\begin{tabular}{|ll|l|l|l|l|l|}
\hline Model & & Sum of Squares & df & Mean Square & F & Sig. \\
\hline 1 & Regression & 1102.897 & 5 & 220.579 & 16.452 & $.009^{\mathrm{a}}$ \\
& Residual & 53.630 & 4 & 13.407 & & \\
& Total & 1156.526 & 9 & & & \\
\hline
\end{tabular}

a. Predictors: (Constant), Liquidity, Growth, ROI, DER, MKT

b. Dependent Variable: Dividend

\section{Coefficients}

\begin{tabular}{|c|c|c|c|c|c|c|}
\hline \multirow{2}{*}{\multicolumn{2}{|c|}{ Model }} & \multicolumn{2}{|c|}{ Unstandardized Coefficients } & \multirow{2}{*}{\begin{tabular}{|l|}
$\begin{array}{l}\text { Standardized } \\
\text { Coefficients }\end{array}$ \\
Beta
\end{tabular}} & \multirow[b]{2}{*}{$\mathrm{t}$} & \multirow[b]{2}{*}{ Sig. } \\
\hline & & B & Std. Error & & & \\
\hline \multirow[t]{6}{*}{1} & (Constant) & 182.787 & 36.079 & & 5.066 & .007 \\
\hline & DER & -.033 & .007 & -.761 & -4.597 & .010 \\
\hline & Growth & 10.054 & 2.667 & .542 & 3.770 & .020 \\
\hline & ROI & -4.619 & 6.996 & -.114 & -.660 & .545 \\
\hline & MKT & -30.910 & 7.918 & -.789 & -3.904 & .017 \\
\hline & Liquidity & .000 & .000 & -.253 & -1.731 & .159 \\
\hline
\end{tabular}

a. Dependent Variable: Dividend 